S. Afr. J. Agric. Ext.

Vol. 45, No. 2, 2017: $14-25$

Zwane, Chauke, Igodan

DOI: http://dx.doi.org/10.17159/2413-3221/2017/v45n2a397

\& Agunga

\title{
A BENCH MARK SURVEY FOR EXTENSION OFFICERS IN THREE DISTRICTS OF LIMPOPO PROVINCE, SOUTH AFRICA
}

Zwane, E. M., ${ }^{2}$ Chauke, P. K., ${ }^{3}$ Igodan, C. ${ }^{4} \&$ Agunga, R. ${ }^{5}$

Correspondence Author: Dr Elliot Zwane. E-mail: elliot.zwane@ul.ac.za or

Zwanefrank@gmail.com.

\begin{abstract}
Extension services is one of the policy instruments which can be used to solve the food insecurity challenges. This understanding has led to a team of extension experts in agricultural extension to organise themselves under the name of Extension Africa. The team saw a need to conduct a benchmark study with the aim of unravelling circumstances facing agricultural extension in selected African countries such as Tanzania, Malawi, Botswana and South Africa. The members of Extension Africa were drawn from these countries. This study presents the situation of three districts in Limpopo Province of South Africa in which thirty extension officers were interviewed using a questionnaire. The findings suggest that there are gaps in the critical areas such as educational levels, job satisfaction, extension methods, communication, extension goal and training needs. It was further revealed that the female extension to male ratio is skewed although they are showing a reasonable level of marital status. The following areas of extension need attention to improve extension delivery: inservice training and Information Communication Technology (ICT). As far as job satisfaction is concerned, the main challenge is linked to salary. The study concludes with a recommendation targeting both the extension managers and policy makers who are encouraged to develop strategies to address the gaps identified by the study.
\end{abstract}

Keywords: Extension, Information Communication Technology, Extension methods Communication, Extension goals.

\section{INTRODUCTION}

There is a general concern that agricultural extension in Africa is not working as well as it should. This has been echoed some years back by a number of researchers (Swanson \& Claar, 1984:7, Röling, 1988:33; Van den Ban \& Hawkins, 1990:41). This paper forms part of a series of ten country papers that sought to assess and benchmark common challenges linked to agricultural extension officers in the following countries: Botswana, Malawi, Uganda, South Africa, Ghana, Nigeria, Senegal, Cameroon and Tanzania. The main aim of the study was to document the current status of extension officers looking at issues broadly, especially those that affect the efficiency of extension services. The key outcome of the study is

\footnotetext{
2 Elliot Zwane $(\mathrm{PhD})$, is a professor for agricultural extension in the Centre for Rural and Community Empowerment, Department of Agricultural Economics and Animal Production. School of Agriculture. University of Limpopo. South Africa. Email: zwanefrank@gmail.com or elliot.zwane@ul.ac.za.

3 Associate Professor, Department of Agricultural Economics and Agribusiness. University of Venda, Thohoyandou, 0950. Email: peakay@univen.ac.za

${ }^{4}$ Professor \& Leader Organization Development, Extension Human Resources College of Food, Agricultural \& Environmental Sciences (CFAES) The Ohio State University. Email: igodan.1@osu.edu. http://extensionhr.osu.edu

${ }^{5}$ Associate Professor \& Director: Centre for African Studies College of Food, Agricultural \& Environmental Sciences (CFAES) Department of Agricultural Communication, Education and Leadership (ACEL). Email: Agunga.1@ osu.edu.
} 
S. Afr. J. Agric. Ext.

Vol. 45, No. 2, 2017: $14-25$

Zwane, Chauke, Igodan

DOI: http://dx.doi.org/10.17159/2413-3221/2017/v45n2a397

\& Agunga

(Copyright)

destined to be shared widely both inside and outside the African continent through researched scientific papers. The specific objectives of this paper are as follows:

To assess the socio-economic status of extension officers in three districts of Limpopo Province of South Africa (gender, marital status, educational qualifications - including actual qualification, number of dependents).

To assess the working conditions and level of job satisfaction (location of work station, job satisfaction, in-service training received, etc.).

To assess on-the job training satisfaction levels and support strategies (desired qualification and specialisation, training received, knowledge of work environment, i.e. local languages, IT support and usage).

\section{BACKGROUND}

The formation of New Partnership for Africa Development (NEPAD) can be seen as the catalyst in streamlining development in Africa and also an admission by the leadership of the continent that something is not right with African development. NEPAD has encouraged the establishment of structures such as Comprehensive Agricultural Advisory Development Programme (CAADP), and later recommended the formation of Africa Forum for Agricultural Advisory Services (AFAAS) through Forum for Africa Research in Africa (FARA), (NEPAD, 2004). These subprograms of NEPAD, have shown positive potential to address some of the concerns of the Millennium Development Goals (MDG) such as poverty and environmental concerns (United Nations, 2000; Blum, 2013:1).

A group of 14 professionals were mobilized in Africa under the name of Extension Africa. They were chosen by the coordinators of the programme who are based in Ohio State University in the United State of America. The reason for the formation of the group was the realization that extension was seen to be facing a lot of challenges and the mission of Extension Africa was to make contribution in terms of doing research work in extension.

The fourteen members were positioned according to three sites in Africa namely North Africa, Eastern Africa and Southern Africa. Studies have been conducted in other study sites. This paper presents work conducted in South Africa in one province. If time is permitting other studies will be conducted which will become the Southern Africa development Communities (SADC). Other research sites of Extension Africa have published their work in scientific journals (Msuya, et al., 2017: 1).

\section{METHODOLOGY}

A team of experts from Extension Africa designed a questionnaire for gathering data related to the specific objectives of the study from their nine countries as reported earlier. Each participating member was responsible for data collection. The collection of data in Limpopo was done using mixed methods sampling procedure. The ideal situation was to collect the sample from the nine Provinces, which was not possible due to the size of the country and limited resources. The second option was to get a sample of sixty questionnaires across the five districts of Limpopo. However due to budgetary constraints data collection was restricted to three districts namely Vhembe, Capricorn and Sekhukhune. 
S. Afr. J. Agric. Ext.

Vol. 45, No. 2, 2017: $14-25$

DOI: http://dx.doi.org/10.17159/2413-3221/2017/v45n2a397

Thirty questionnaires were distributed to the Managers of Advisory Services, who in turn distributed the questionnaires randomly to the extension officers. Each questionnaire was accompanied by an introductory message on the topics to be covered. Prior to the conducting of the interview which each respondent completed the questionnaire, a letter requesting authority to collect data was sought from the senior management of the Department of Agriculture in Limpopo. After approval was granted data collection proceeded during February of 2011. Thirty questionnaires were completed by individual extension officers. The questionnaires were shipped to Ohio State University for filtering, capturing into the SPSS computer programme for processing.

A further analysis was done to enable more analysis. Limpopo Province is located in the northern most part of South Africa and it is one of the nine provinces constituting the country. The province itself consist of five District Municipalities, i.e. Capricorn at the centre, Sekhukhune to the South, Waterberg in the western side, Mopani in the East and Vhembe to the north. Out of a total number of 300 extension officers in the three districts excluding the other two, a sample of 30 was randomly selected from three districts of Limpopo Province, i.e. Capricorn (12), Sekhukhune and Vhembe (9 each).

\subsection{Data analysis}

Collected data were captured into the SPSS Version 23 IBM programme and analysed using cross tabulations statistical technique. Furthermore, data were cross tabulated, analysed and compared using the variables against the results of one or more variables.

\section{RESULTS AND DISCUSSION}

It is important to know the type of clients before developing any training programme. The following elements of demography were tested gender, education, marital status and language proficiency.

\subsection{Location of study site}

The study was conducted in the three districts of Limpopo, namely Mopani, Waterberg and Vhembe.

\subsection{Socio economic conditions of extension officers}

\subsubsection{Gender and position of respondents}

The majority of the respondents were male (70\%). This is not surprising because a study conducted in other provinces of South Africa display a similar tendency (Zwane, 2009: 37). The gender and position of extension officers is reflected in Table 1. 
S. Afr. J. Agric. Ext.

Vol. 45, No. 2, 2017: $14-25$

DOI: http://dx.doi.org/10.17159/2413-3221/2017/v45n2a397
Zwane, Chauke, Igodan

\& Agunga

(Copyright)

Table 1: Gender and position of extension workers in the Limpopo Province Department of Agriculture (LDA) (\%)

\begin{tabular}{|c|c|c|c|c|}
\hline \multicolumn{2}{|l|}{ Position } & \multicolumn{3}{|c|}{ Gender (\%) } \\
\hline & & Male & Female & Total \\
\hline \multirow{4}{*}{$\begin{array}{l}\text { Agricultural } \\
\text { Scientists }\end{array}$} & Crop Science Specialist & 10 & 0 & 10 \\
\hline & Agricultural Economist & 3.3 & 0 & 3.3 \\
\hline & Animal Health Specialist & 6.7 & 0 & 6.7 \\
\hline & Senior Agricultural scientist & 3.3 & 0 & 3.3 \\
\hline \multicolumn{2}{|c|}{ General agricultural advisors } & 46.7 & 16.7 & 63.4 \\
\hline \multicolumn{2}{|c|}{ Deputy Manager } & 0 & 3.3 & 3.3 \\
\hline \multicolumn{2}{|c|}{ Other } & 0 & 10 & 10 \\
\hline \multicolumn{2}{|l|}{ Total } & 70 & 30 & 100 \\
\hline
\end{tabular}

This could be seen as a legacy of colonialism and recent apartheid manifestations which used to see the position of women as minor, especially in the job situation (Wikipedia, 2017). However, the position of women has changed since the dawn of democracy in South Africa as there are equal opportunities for women to follow any career of their choice.

The position of extension officers in the LDA is categorised into three levels, namely; development officer, agricultural advisor, senior advisor, and agricultural scientist/specialist (Mkhize, 2013:9). The concept or designation of agricultural officers has assumed a broad definition, which refers to any extension officer who provides technical knowledge. It includes those who provide information from the economic or animal perspective. The study found that the majority were agricultural advisors (63.3\%) with agricultural scientists constituting close to a quarter (23.3\%). Most agricultural scientists have specialised in crop (10) and animal (6.7) production. The proportion of workers holding Agricultural Economics is very few (3.3\%). Deputy Managers and other designations constituted $13.3 \%$ of the extension component. Despite their small proportion, female extension officers are more dominant in senior managerial positions (deputy managers).

\subsubsection{Ages of respondents}

Most $(48.3 \%)$ extension officers in the employ of the LDA were in the 41-50-year category, located mostly in the Capricorn district (27.6\%). A significant proportion $(20.7 \%)$ was in the younger 20-30 years group, especially in the Vhembe district (10.3\%). The ages of respondents are reflected in Table 2.

Table 2: Age spread of extension workers in the Limpopo Province Department of Agriculture (LDA) (\%)

\begin{tabular}{|l|l|l|l|l|l|l|}
\hline District & \multicolumn{7}{l}{ Age spread of respondents (\%) } & & & \\
\hline & & & & & & \\
& $=<25$ yrs. & $26-30$ yrs. & $31-40$ yrs. & $41-50 \mathrm{yrs}$ & $=>51$ yrs. & \\
\hline Vhembe & 0.0 & 10.3 & 6.9 & 13.8 & 6.9 & 37.9 \\
\hline Sekhukhune & 0.0 & 6.9 & 3.4 & 6.9 & 0.0 & 17.2 \\
\hline Capricorn & 3.4 & 3.4 & 3.4 & 27.6 & 7.1 & 44.9 \\
\hline \multicolumn{7}{l}{} \\
\hline
\end{tabular}


S. Afr. J. Agric. Ext.

Vol. 45, No. 2, 2017: $14-25$

DOI: http://dx.doi.org/10.17159/2413-3221/2017/v45n2a397
Zwane, Chauke, Igodan

\& Agunga

(Copyright)

Considering that in South Africa youth are considered as all individuals from 35 years and below (National Youth Policy, 2015: 2), it can be concluded that about 30 of extension officers in the employ of the LDA are youth (i.e. $24.1 \%$ and almost half of $13.8 \%$ ). The figure augers well for sustaining the management of agricultural activities in the province.

\subsubsection{Educational qualification}

According to Schwass \& Allo (1982:3), the basic training of an agricultural technician must include technical knowledge, a sound knowledge of people and rural communities as well as agricultural processes and skills to communicate effectively. Respondents were asked about the highest level of educational achieved. The results are depicted in Table 3.

Table 3: Educational achievements of extension workers in the Limpopo Province Department of Agriculture (LDA) (\%)

\begin{tabular}{|l|l|l|l|l|l|}
\hline District & \multicolumn{3}{l}{ Highest level of education achieved (\%) } & Total \\
\hline & Diploma & $\begin{array}{l}\text { Machelor's } \\
\text { Degree }\end{array}$ & $\begin{array}{l}\text { Master's } \\
\text { Degree }\end{array}$ & $\begin{array}{l}\text { Secondary } \\
\text { Education }\end{array}$ & \\
\cline { 2 - 6 } & 3.3 & 23.3 & 6.7 & 3.3 & 36.6 \\
\hline Vhembe & 10.0 & 10.0 & 0.0 & 0.0 & 20.0 \\
\hline Sekhukhune & 13.3 & 10.0 & 13.4 & 6.7 & 43.4 \\
\hline Capricorn & 26.7 & 43.3 & 20.0 & 10.0 & 100.0 \\
\hline TOTAL & & &
\end{tabular}

Extension officers in South Africa and in Limpopo benefited from the Extension Recovery Plan (ERP) under the pillar of re-skilling (Mkhize, 2013:7). According to Table 3, most extension officers in the LDA have acquired Bachelors and Masters Degrees (43.3\% and 20\% respectively). The worrying observation though is that almost one in 10 extension officers still hold only secondary education. The proportion is not satisfactory especially in that out of 2210 extension officers in the country, 1768 throughout South Africa were given state bursaries to upgrade their qualifications between 2010 and 2013. However, only 330 (or $15 \%$ ) successfully upgraded their qualifications with only $1.4 \%$ emanating from Limpopo Province (Mkhize, 2013:10). The question to be asked is, why extension officers are not motivated to upgrade their qualifications although this is a requirement by the Norms and Standard of extension in South Africa (Norms and Standards, 2005).

\subsubsection{Marital status of respondents}

Table 4 reveals that most $(76.7 \%)$ respondents were married. However, only a small percentage showed different results. The reason was either a separation or a divorce.

Table 4: Marital status of extension workers in the Limpopo Province Department of Agriculture (LDA) (\%)

\begin{tabular}{|l|l|l|l|l|}
\hline \multirow{2}{*}{ District } & \multicolumn{2}{|l|}{ Marital Status (\%) } & Total \\
\hline & Married & Single & Divorced/separated & \\
\hline Vhembe & 26.7 & 6.7 & 3.3 & 36.7 \\
\hline Sekhukhune & 20.0 & 0.0 & 0.0 & 20.0 \\
\hline Capricorn & 30.0 & 13.3 & 0.0 & 43.3 \\
\hline Total & 76.7 & 20.0 & 3.3 & 100.0 \\
\hline
\end{tabular}


S. Afr. J. Agric. Ext.

Vol. 45, No. 2, 2017: $14-25$

DOI: http://dx.doi.org/10.17159/2413-3221/2017/v45n2a397

Divorced extension workers were mostly located in the Vhembe district, this was also the district with more extension advisors.

\subsubsection{Number of dependents}

Table 5 shows that the average number of dependents was 2.5 with a standard deviation of 1.4 depicting that most household had about one to 4 members. The maximum number of dependents was six, although some households had no dependents. The higher maximum number of dependents reflects commitment on the part of extension officers to look after other members of their families.

Table 5: Number of dependants in household $(n=30)$

\begin{tabular}{|l|l|l|l|l|l|l|}
\hline District of work & Mean & $\mathbf{N}$ & Std. Deviation & Median & Minimum & Maximum \\
\hline Vhembe & 2.82 & 11 & 1.779 & 2.00 & 0 & 6 \\
\hline Sekhukhune & 2.50 & 6 & .837 & 3.00 & 1 & 3 \\
\hline Capricorn & 2.23 & 13 & 1.301 & 3.00 & 0 & 3 \\
\hline Total & 2.50 & 30 & 1.408 & 3.00 & 0 & 6 \\
\hline
\end{tabular}

\subsection{Assessment of working environment and level of job satisfaction}

\subsubsection{Location of work station and ability to speak the local language}

Extension officers are recommended to stay in the villages where their clients live (Bembridge 1990:195). This help in creating trust to the extension officers by the villagers and the farmers. The LDA has developed a policy of ensuring that the placement of extension officers be based on individual needs through negotiation rather than a top down approach. This ensures that no one goes to places where they can't speak the local languages. The study found more than half of the extension officers $(53.3 \%)$ operated from sub-district levels with many $(43.3 \%)$ operating from the village level. It was also found that only $43.3 \%$ were residing in the same area of work. This situation was not so in the past, the Department used to provide housing accommodation however when extension officers became mobile they tended to vacate government accommodation and sought their own.

Table 6: Area of operation and ability to speak local languages of extension workers in the Limpopo Province Department of Agriculture (LDA) (\%)

\begin{tabular}{|c|c|c|c|c|}
\hline \multirow[b]{2}{*}{ Response } & \multirow[b]{2}{*}{ Village } & \multicolumn{3}{|c|}{ Area of operation } \\
\hline & & Sub-district & District & Total \\
\hline Vhembe & 23.4 & 10.0 & 3.3 & 36.7 \\
\hline Sekhukhune & 0.0 & 20.0 & 0.0 & 20.0 \\
\hline Capricorn & 20.0 & 23.3 & 0.0 & 43.3 \\
\hline \multirow[t]{2}{*}{ Total } & 43.4 & 53.3 & 3.3 & 100.0 \\
\hline & \multicolumn{4}{|c|}{ Ability to speak the local language in work station (\%) } \\
\hline Response & & Yes & No & Total \\
\hline Vhembe & & 28.6 & 3.6 & 32.1 \\
\hline Sekhukhune & & 21.4 & 0.0 & 21.4 \\
\hline Capricorn & & 35.7 & 10.7 & 46.4 \\
\hline Total & & 85.7 & 14.3 & 100.0 \\
\hline
\end{tabular}


S. Afr. J. Agric. Ext.

Vol. 45, No. 2, 2017: $14-25$

DOI: http://dx.doi.org/10.17159/2413-3221/2017/v45n2a397
Zwane, Chauke, Igodan

\& Agunga

(Copyright)

Effective communication involves both verbal and non-verbal activities. According to Hoffman, Gerster-Bentaya, Christinck \& Lemma, (2009:114), communication involves the process which is fundamental to extension, training and passing on of information. The study found that the majority of extension officers $(85.7 \%)$ could speak the languages of work. The Capricorn District had the highest proportion of extension officers that could not speak the local language $(10.7 \%)$. Not reflected in the table is the finding that few respondents could write the predominately spoken language with many more $(73 \%)$ reflecting that they could not. Testing whether the extension officers were able to speak the predominately national language of their country, many $(53.3 \%)$ indicated that they were able to do so.

This finding is doubtful, because there might be a misunderstanding between what a national language is all about. In South Africa, there are 11 official languages and English is not only seen as a uniting language but also a critical component of the business environment. The extension officers have reasonable command of the English language. In another question testing the ability to speak and write the English language, $80 \%$ of the respondents can write and speak English. This is not surprising because the extension officers have received their tertiary education where the language used was English. Respondents were further asked whether they can speak and write in French, the response was $100 \%$ not able to do so. French is not a common language used in the rural areas and urban areas of Limpopo.

\subsubsection{Level of job satisfaction and access to IT}

Seven variables were identified to test the job satisfaction of extension officers. The following scale was used: very dissatisfied, dissatisfied, satisfied, moderately satisfied and very satisfied.

Table 7: Level of job satisfaction of extension workers in the Limpopo Province Department of Agriculture (LDA) (\%) (n=30)

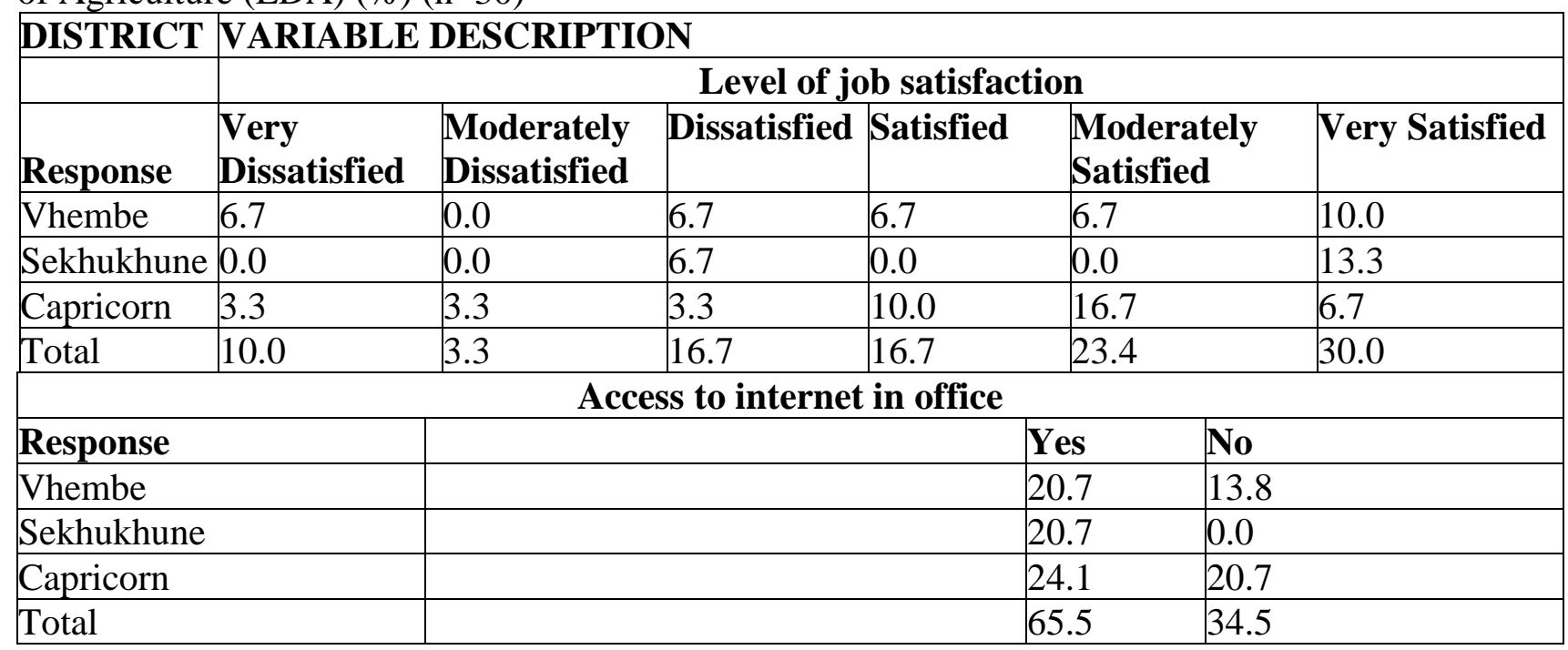

Table 7 shows that almost three quarters $(70 \%)$ of the extension officers were satisfied with their working environment. However, $10 \%$ of extension officers indicated that they were very much dissatisfied with their work conditions. Regarding access to IT (especially internet), many extension officers in the LDA responded affirmatively $(65.5 \%)$. However, the fact that $34 \%$ of the extension officers reported non-access to this critical resource should be a matter of concern to the LDA management. 
S. Afr. J. Agric. Ext.

Vol. 45, No. 2, 2017: $14-25$

DOI: http://dx.doi.org/10.17159/2413-3221/2017/v45n2a397
Zwane, Chauke, Igodan

\& Agunga

(Copyright)

\subsection{Specialisation of extension officers}

The following areas of specialisation became clear from the study namely agronomy accounted for $20 \%$, animal production $13.3 \%$, extension $6.7 \%$ and sustainable agriculture $10 \%$. It is surprising to see a low percentage of specialisation in extension. One would have expected more specialisation in extension. The cause of this was created by the perception formed that during the upgrading process, extension was shaking in the Department, due to the decentralisation of the extension directorate to the districts in 2008.

\subsection{Highest level desired to achieve}

In 2010, all extension officers in South Africa who did not already have a four-year degree qualification were given a three-year period of grace for upgrading, i.e. from 2010 to 2013 (Norms and Standards, 2005). Respondents were asked which highest level of education would satisfy them if they achieve it. The responses are as follows: Sixty six percent desired to have a Bachelor degree, $6 \%$ desired to have a Diploma, $6 \%$ desired to have an honours degree, $36.6 \%$ desired to have a Master's degree and $43.3 \%$ desired to have a $\mathrm{PhD}$ degree.

One is not surprised to observe a lower percentage desiring a diploma. This is so because there are special auxiliary officers who were being used as extension officers, who were hired as assistants to extension officers especially from Capricorn district, whose qualifications were just a standard 10 and lower. As indicated, the Norms and Standard does not allow the continuation of this situation.

\subsection{In-service training attended}

Experience has shown that in service training plays an important role in bringing motivation because extension officers feel confident on issues that are critical in their profession. Zwane (2009:65) confirmed that without resources such as information extension officers feel discouraged to visit farmers. Thirty percent have attended in-service training only once, $40 \%$ have attended the in-service training twice and $23 \%$ attended three times. It is only a lower $6.7 \%$ that have attended more than 4 times. This situation is not a true reflection because there is a system which facilitate in service training.

The Human Resource Development unit has courses targeting individual extension officers taken from their Performance Management Development as part of individual competency based training. It was agreed by $43.3 \%$ that the training included agriculture, $46.6 \%$ agreed that the in-service training also included leadership/ supervisory issues and $43.3 \%$ covered administration/management. Only $26.7 \%$ said the in-service training included communication skills. It is important that extension advisors always be refreshed in their training to be abreast of new trends in development.

\subsection{Job satisfaction}

Seven variables were identified to test the job satisfaction of extension officers. The following scale was used: very dissatisfied, dissatisfied, satisfied, moderately satisfied and very satisfied. Looking at the outcome based on this scale it showed a lower output which did not reflect a convincing conclusion. The level of satisfaction is reflected in Figure 1. 


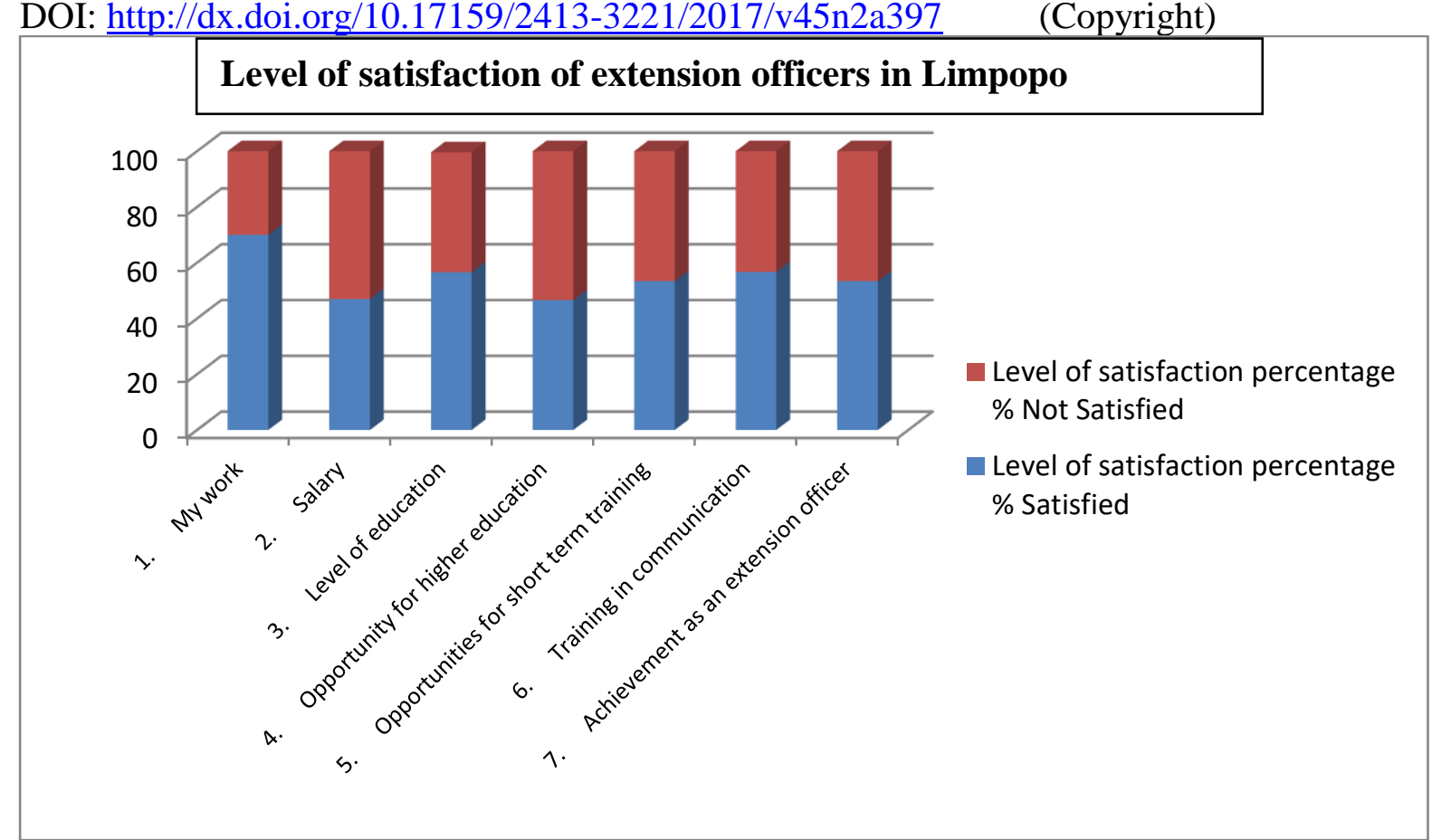

Figure 1: Level of satisfaction

Figure 1 reflects a positive situation of the job satisfaction. However, four factors show performance of $50 \%$ and one performed less than $50 \%$. As far as these performances are concerned, the two levels not satisfied are the salary and their desire to upgrade their qualifications. The possible cause in the salary might be linked to the Occupational Specific Dispensation $(\mathrm{OSD})^{6}$ which some officers feel must be addressed. The Department introduced OSD in 2009 and the extension officers have been excluded. However, issues identified were to some extend linked to South African Council for Natural Scientific Professions (SACNSP). This body expected the scientists to be registered and have a certificate of practice. This is an ongoing process where each professional practitioner has to be registered with SACNASP.

It is generally accepted that ICT gadgets can play a role in creating innovations as well as improving the face of agricultural extension. According to (Hoffman et al., 2009: 163), ICT has gone electronic. Computers and electronic storage facilities are getting cheaper and cheaper. Mobile phones are developing into universal communication devices, connecting computers can be found in nearly all offices and internet access is spreading. Extension officers were asked to assess whether they have access to various ICT tools. They were asked to indicate yes or no. The findings are indicated in Figure 2.

\footnotetext{
${ }^{6}$ OSD is a concept promoted by the South African Government in which a specific group of professions were identified as scarce skills and were given recognition in terms of salary. The professions falling under this determination were rewarded handsomely. In agriculture, few professional groups like engineers, scientists, and cartographers are included, but agricultural extensionists were left out. Extension practitioners have approached their principals who approached the National Department who said the OSD is closed and cannot be extended to the extension officers.
} 


\section{Access to ICT tools}

9. Own website of ministry

8. Own land line

7. Own $\mathrm{mp} 3 / 4$ players

6. Own cellphone

5. Own internet in cyber café

4. Own internet within office

3. Own laptop

2. Own desktop

1. Own software (outlook,...

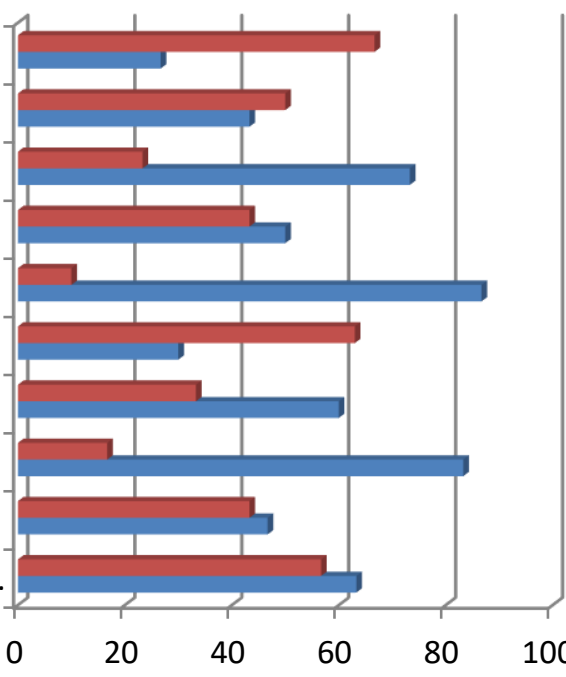

no access (no)

- Have access (yes)

Figure 2: Information Communication Technology (ICT) tools

According to Figure 2, there was a high percentage of access to ICT tools. There were few ICT tools which were not properly completed, they included own fax, skype account, use of e-discussion, listeners/newsgroup, use of presentation software, use of statistical analysis software, (SPSS, SAS, Minitab), use of e-agriculture news, use of e-conference, use video camera, use of LCD projector, use of video cassette recorder and use of television set. Out of seven ICT tools five showed a lower rating below $40 \%$ of access. It is worth noting that as far as access to ICT tools in Limpopo is concerned the efforts of Limpopo Department of Agriculture are commendable. According to Mkhize (2013:7), the inception of the Extension Recovery Programme (ERP) in 2008, with its five pillars namely: Visibility and Accountability, Image and Professionalism, Recruiting, Re-skilling, ICT infrastructure, in 2008 in South Africa has benefited all provinces, including Limpopo. The support came to Limpopo as a "package" consisting of "tools" to support extension officers. For example, extension officers were allocated with subsidised vehicles, laptops, or desk top computers, cell phones compatible with $3 \mathrm{G}$ facilities in order to access the internet services.

The Limpopo Department of Agriculture (LDA) has provided extension officers with internet reference system which is called Extension Suite Online and Agri-Suite, both systems are like an Agri-pedia system which capacitate the extension officers with the latest development in the areas of crops, animal, marketing and resource utilisation. Furthermore, they have access to attend at least one annual District Extension Conference. Depending on the availability of funds and their envisaged roles in the conferences, they can also attend Provincial Extension Conferences, join National Extension Professional Societies of their choices such as the South African Society of Agricultural Extension (SASAE), Crop and Water Irrigation Society Agricultural Economics of South Africa and Animal Society of South Africa.

\section{CONCLUSION AND RECOMMENDATIONS}

The study has provided insight on the perceptions of extension officers in Limpopo Province with regards to the critical areas such as demography, educational levels, job satisfaction, and ICT tools. Most of the respondents were born in rural areas and raised there, which is an 
S. Afr. J. Agric. Ext.

Vol. 45, No. 2, 2017: $14-25$

DOI: http://dx.doi.org/10.17159/2413-3221/2017/v45n2a397
Zwane, Chauke, Igodan

\& Agunga

(Copyright)

advantage in terms of understanding the dynamics of rural development especially that they could also fit well due to the fact that more than $90 \%$ are able to communicate in the local language in the areas where they operate as extension officers. The study also revealed that the female extension to male ratio is skewed, although they are showing a reasonable level of marital status.

The level of in-service training needs was also found to be inadequate, hence a need to be strengthened. When looking at the level of job satisfaction, the situation is not satisfactorily because on the one hand they are satisfied with much support provided by the Department through the Extension Recovery Program, while on the other they flagged salary as an issue. Despite all the efforts of package support there is an observation that salary and educational level need to be improved. As far as access to ICT tools is concerned there are serious gaps which make that extension do not realise their maximum influence due to limited usage of certain tools.

The focus of the study was to look internally to the extension officers in a form of developing a baseline, hoping that it will contribute in documenting the situation of Limpopo Department of Agriculture and Rural development. The writers believe that if sufficient capacity is built, among the extension officers, farmers will indirectly benefit too. Based on the findings of the study the following recommendations were made:

Extension managers and policy makers have a responsibility to ensure that extension officers are capacitated through in-service training in the specified areas identified by the study.

Capacitating extension officers will contribute towards alleviating poverty, thereby strengthen their resolve to improve the living standards of farmers. The study has provided the guidance in resolving the developmental challenges faced by extension practitioners, which if resolved will contribute in resolving challenges of small holder farmers in Limpopo.

\section{REFERENCES}

BEMBRIDGE, T.J. 1991. The Practice of Agricultural Extension. A Training Manual. Development Bank of Southern Africa, Half way House, Midrand.

BLUM, M. 2013. Food security in the world. A paper presented in the SASAE Conference held in Bloemfontein, University of Free State.

DÜVEL, G. 2002. Towards Developing an Appropriate Extension Approach, Purposeful or Programmed Extension. Business Enterprise, University of Pretoria.

HOFFMAN, V., GERSTER-BENTAYA. M., CHRISTINCK. A. \& LEMMA. M. 2009. ICT an Integrative tool. Rural Extension. Vol.1: Basic Issues and Concepts. $3^{\text {rd }}$ Edition. Margraf Publishers.

MKHIZE, Z. 2013. Five-year journey of Extension Recovery Program. Presentation Delivered during Sekhukhune District Extension. Department of Agriculture Forestry and Fisheries.

MSUYA, C.P., ANNOR-FREMPONG, F.K., MAGHENI, M.N., AGUNGA, R., IGODAN, C.O., LADELE, A.A., HUHELA, K., TSELAESELE, N.M., MSATILOMO, H., CHOWA, C., ZWANE, E.M., MIIRO, R., BUKEYN, C., KIMA, L.A., MELIKO, M. \& NDIAYE, K. 2017. The role of Agricultural Extension in Africa's Development, the importance of extension workers and the need for change, Int. J. Agr. Ext. 05 (01) 2017. 59-70 available online: Esj journals. ISSN: 2311-6110 (Online), 2311-8547 (Print) http://www.escijournals.net/IJAE

NORMS AND STANDARDS, 2005. Support programmes requiring extension and advisory services Department of Agriculture Forestry and Fisheries, Pretoria. 
S. Afr. J. Agric. Ext.

Vol. 45, No. 2, 2017: $14-25$

Zwane, Chauke, Igodan

DOI: http://dx.doi.org/10.17159/2413-3221/2017/v45n2a397

\& Agunga

(Copyright)

NATIONAL YOUTH POLICY, 2015. National Youth Policy 2015-2020. Accessed 19 December 2017 on line at: www.thepresidency.gov.za>file>fid

NEW PARTNERSHIP FOR AFRICA DEVELOPMENT (NEPAD). 2004. Comprehensive African Agricultural Development Programme (CAADP) Pillar IV. Internet accessed 18 September 2013.

RÖLING, N. 1988. Extension science: Information systems in agricultural development types of extension. Cambridge University Press, Cambridge.

SCHWASS, R.H. \& ALLO, A.V. 1982. Training the extension worker. Professional requirements of the extension worker. Course content for training extension service personnel. Food and technology Centre Extension bulletin. Ministry of Agriculture, Tel Aviv, Israel.

SWANSON, B.E. \& CLAAR, J.B. 1984. Agricultural extension: A reference manual. Alternative models and recent trends in organizing agricultural Extension. Food and Agriculture Organization of the, United Nations. Rome.

UNITED NATIONS. 2000. Millennium Development Goals. New York. Accessed on the 10 August 2016 www.un.org $>2015$ MDG-Report $>$ pdf.

VAN DEN BAN, A.W. \& HAWKINS, H.S. 1988. Agricultural extension: Definition of extension. The extension research linkage. Longmans Scientific and Technical, New York.

WIKIPEDIA, 2017.Women in South Africa. The effects of apartheid on status of women. Accessed online on the 18 December 2017 at https://en.m.wikipedia.org>wiki>Women...

ZWANE E.M. 2009. Participatory development of an extension approach and policy for Limpopo Province, South Africa Department of Agricultural Economics, Extension and Rural Development, Faculty of Natural and Agricultural Sciences, PhD Thesis, University of Pretoria. 